Jurnal Health Sains: p-ISSN: 2723-4339 e-ISSN: 2548-1398

Vol. 3, No. 1, Januari 2022

\title{
ANALISIS SEBARAN SPASIAL KERAWANAN PENYAKIT DEMAM BERDARAH DENGUE DI KOTA MEDAN
}

\section{Sulastri Purba, Nurmaini Khalik, Sri Malem Indirawati}

Fakultas Kesehatan Masyarakat, Universitas Sumatera Utara, Indonesia

Email: sulastripurba44@gmail.com, nurmainik@yahoo.com, srimalem@usu.ac.id

\begin{tabular}{ll}
\hline INFO ARTIKEL & ABSTRAK \\
\hline Diterima & Penyakit Demam Berdarah Dengue adalah penyakit endemis di Kota \\
5 Januari 2022 & Medan. Iklim mengubah dinamika transisi vektor penyebar penyakit dan \\
Direvisi & kepadatan penduduk menyebabkan peningkatan kontak antara vektor \\
15 Januari 2022 & dan manusia. Penelitian ini bertujuan menganalisis secara spasial \\
Disetujui & distirbusi demam berdarah dengue berdasarkan kondisi iklim dan \\
25 Januari 2022 & kepadatan penduduk di Kota Medan dengan pendekatan studi ekologi \\
\hline Kata Kunci: & dengan menggunakan data sekunder. Analisis data dilakukan secara \\
demam berdarah & univariat, bivariat dengan menggunakan uji korelasi Spearman dan \\
dengue; iklim; & Pearson. Hasil penelitian menunjukkan secara statistik ada hubungan \\
kepadatan & kejadian DBD dengan suhu udara $(\mathrm{r}=-0,374$ dan p=0,001), kelembaban \\
penduduk; spasial & (r =-0,370 dan p=0,001), sedangkan kejadian DBD tidak memiliki \\
& hubungan dengan curah hujan $(\mathrm{r}=0,078$ dan $\mathrm{p}=0,516)$ dan kepadatan \\
& penduduk $(\mathrm{r}=-0,180$ dan $\mathrm{p}=0,067)$. Dari hasil secara spasial daerah \\
& kerawanan tinggi DBD adalah Kecamatan Medan Tuntungan, Medan \\
& Johor, Medan Denai, Medan Selayang, Medan Sunggal, Medan Helvetia, \\
& Medan Deli.
\end{tabular}

\begin{abstract}
Dengue Hemorrhagic Fever is an endemic disease in Medan City. Climate changes transition dynamic (behavior, biological cycles, species) of disease vectors and population density leads to an increased contact between vectors and humans. This study was aimed to analyze spatially distribution of dengue fever based on climatic conditions and population density in Medan City with an ecological study approach by using secondary data. Data analysis was carried out univariately, bivariately by using the Spearman and Pearson correlation test. The results showed statistically that there was a relationship between the incidence of DHF with air temperature ( $r=-0.374$ and $p=0.001)$, humidity $(r=-0.370$ and $p=0.001)$, while the incidence of DHF had no density $(r=-0.180$ and $p=0.067)$. From the spatially results, high-risk areas for DHF are Medan Tuntungan District, Medan Johor, Medan Denai, Medan Selayang, Medan Sunggal, Medan Helvetia, Medan Deli.
\end{abstract}

Keywords: dengue hemorrhagic relationship with rainfall $(r=0.078$ and $p=0.516)$ and population fever climate; population density; spatial

\section{Pendahuluan}

Demam Berdarah Dengue (DBD) adalah penyakit infeksi yang disebabkan virus dengue dengan vektor perantara Aedes Spp. Demam dengue (dengue fever) disebabkan oleh virus serotipe DEN-1, DEN-2, DEN-3, dan DEN-4. Demam berdarah dengue ditandai dengan demam 2 hingga 7 hari disertai pendarahan, hemokonsentrasi (ditandai dengan kebocoran plasma dan penurunan trombosit), serta gejala tidak khas
How to cite:

E-ISSN:

Published by: 
seperti nyeri otot dan tulang, nyeri kepala, dan ruam (Kemenkes RI, 2017).

Rencana Strategis Indonesia tahun 2015-2019, IR DBD < 49 per 100.000 penduduk tidak memenuhi target pada 23 provinsi di Indonesia, salah satunya adalah Provinsi Sumatera Utara. Jumlah IR Sumatera Utara pada tahun 2019 adalah 60,6 per 100.000 penduduk dengan 7.731 kasus dan 38 kematian $(\mathrm{CFR}=0,49 \%)$ (Kemenkes RI, 2020). Kota Medan adalah sentra pemerintahan Daerah Tingkat I Sumatera Utara memiliki luas wilayah $265,10 \mathrm{Km} 2$, jumlah penduduk berjumlah 2.435.252 jiwa, kepadatan penduduk mencapai 9,186 Jiwa/ $\mathrm{Km}^{2}$ (Badan Pusat Statistik Kota Medan, 2020). Kota Medan adalah daerah endemis DBD ke dua setelah Kabupaten Deli Serdang dari 33 kabupaten/kota di Sumatera Utara, yaitu sebanyak 1.068 kasus (Dinas Kesehatan Provinsi Sumatera Utara, 2019). Angka kesakitan (Insidence rate, $I R$ ) DBD di Kota Medan pada tahun 2015 - 2018 mengalami peningkatan dan penurunan. Pada tahun 2015, IR DBD sebesar 61 per 100.000 penduduk, meningkat pada tahun 2016 menjadi $I R 80$ per 100.000 penduduk, turun menjadi $I R 56$ per 100.000 penduduk pada tahun 2017, kemudian meningkat menjadi IR 66 per 100.000 penduduk pada tahun 2018 .

Faktor penting dalam penularan infeksi virus dengue, yaitu host, agent, dan lingkungan (Suwandono et al., 2019). Kondisi lingkungan yaitu iklim (suhu udara, kelembaban udara, curah hujan) dan kepadatan penduduk mempengaruhi penularan virus dengue (Kemenkes RI, 2017). Suhu $25{ }^{0} \mathrm{C}$ menunjukkan bahwa nyamuk betina berumur lebih panjang daripada nyamuk jantan (Soedarto, 2012). Kelembaban nisbi lebih dari $60 \%$ merupakan keadaan ideal untuk habitat nyamuk Aedes aegypti, umur nyamuk menjadi lebih panjang dan berpotensi menjadi infektif dalam menularkan dengue. Sementara itu, kelembaban nisbi kurang dari $60 \%$ umur nyamuk menjadi pendek dan tidak dapat menjadi vektor (Suwandono et al., 2019). Curah hujan lebih dari $200 \mathrm{~mm}$ per tahunnya menyebabkan kepadatan populasi Aedes aegypti (Soedarto, 2012). Penyakit demam berdarah dengue semakin luas penyebarannya sejalan dengan meningkatnya kepadatan penduduk (Kemenkes RI, 2017). Hal ini terjadi karena adanya peningkatan kontak antara vektor dengan manusia (Suwandono et al., 2019).

Sistem informasi geografis dapat dimanfaatkan untuk mencari hubungan sebab akibat kejadian penyakit (Rahmanti \& Prasetyo, 2012). Analisis spasial menghasilkan identifikasi daerah berisiko tinggi, persebaran kasus, tren waktu, dan memperkirakan terjadinya kasus di masa datang (Sunaryo, 2015). Yana dan Rahayu (2017) menemukan bahwa distribusi kasus DBD memiliki hubungan spasial dan dapat menggambarkan distribusi kasus DBD yang berkaitan dengan faktor lingkungan di Temanggung.

Kondisi iklim (suhu, kelembaban dan curah hujan) di Kota Medan kondusif bagi perkembangbiakan nyamuk sehingga meningkatkan kepadatan vektor Aedes aegypti yaitu iklim tropis dengan suhu udara rata-rata tahun 2020 yaitu $27{ }^{\circ} \mathrm{C}$, kelembaban udara $82 \%$, dan curah hujan per bulannya 228,5 mm. Meningkatnya kepadatan penduduk di Kota Medan juga menyebabkan nyamuk Aedes aegypti semakin mudah menularkan virus dengue ke satu orang ke orang lain (Badan Pusat Statistik Kota Medan, 2020). Penelitian ini bertujuan menganalisis secara spasial kerawanan penyakit demam berdarah dengue di kota medan berdasarkan iklim dan kepadatan penduduk.

\section{Metode Penelitian}

Penelitian ini menggunakan desain studi ekologi berdasarkan data aggregate atau populasi. Penelitian dilaksanakan di Kota Medan. Populasi dan sampel dalam penelitian 
ini adalah seluruh laporan dari bulan Januari 2015 hingga Desember 2020 yaitu data kasus demam berdarah dengue dari Dinas Kesehatan Kota Medan, data faktor iklim (suhu udara, kelembaban, dan curah hujan) diperoleh dari laporan Badan Meteorologi, Klimatologi, Klimatologi, dan Geofisika (BMKG) Stasiun Klimatologi Sampali, dan kepadatan penduduk di Kota Medan diperoleh dari laporan Badan Pusat Statistik Kota Medan. Penelitian ini menggunakan sumber data yaitu data sekunder.

\section{Skor Akhir $=$ \\ $\left(10^{*}[\right.$ Skor suhu udara $\left.]\right)+\left(30^{*}[\right.$ Skor kelembaban udara $\left.]\right)+\left(25^{*}[\right.$ Skor curah hujan $\left.)\right]+$ ( $35^{*}[$ Skor kepadatan penduduk])}

Tabel 1

Klasifikasi Variabel Penelitian

\begin{tabular}{llll}
\hline Variabel & Klasifikasi & Skor & Zona \\
\hline \multirow{2}{*}{ Suhu Udara } & $<21^{\circ} \mathrm{C}$ & 1 & Rendah \\
\cline { 2 - 4 } & $21^{\circ} \mathrm{C}-25^{\circ} \mathrm{C}$ & 2 & Sedang \\
\cline { 2 - 4 } & $>25^{\circ} \mathrm{C}$ & 3 & Tinggi \\
\hline Kelembaban Udara & $<60 \%$ & 1 & Rendah \\
\cline { 2 - 4 } & $60 \%-80 \%$ & 2 & Sedang \\
\cline { 2 - 4 } & $>80 \%$ & 3 & Tinggi \\
\hline Curah Hujan & $<100 \mathrm{~mm} / \mathrm{bulan}$ & 1 & Rendah \\
\cline { 2 - 4 } & $100 \mathrm{~mm}-300 \mathrm{~mm} / \mathrm{bulan}$ & 2 & Sedang \\
\cline { 2 - 4 } & $>300 \mathrm{~mm} / \mathrm{bulan}$ & 3 & Tinggi \\
\hline Kepadatan Penduduk & $<500 \mathrm{Jiwa} / \mathrm{Km}^{2}$ & 1 & Rendah \\
\cline { 2 - 4 } & $500-10.000 \mathrm{Jiwa} / \mathrm{Km}^{2}$ & 2 & Sedang \\
\cline { 2 - 4 } & $>10.000 \mathrm{Jiwa} / \mathrm{Km}^{2}$ & 3 & Tinggi \\
\hline
\end{tabular}

Sumber: Analisis Data (2021)

Hasil analisis skoring dan pembobotan terhadap keempat variabel yang digunakan kemudian diklasifikasikan kembali untuk mendapatkan peta kerawanan DBD. Selang
Analisis data yaitu dengan metode overlay menggunakan aplikasi ArcView 10.4, yaitu mengolah data berupa peta dasar Kota Medan yang dioverlay dengan variabilitas iklim dan kepadatan penduduk. Hubungan antara kejadian DBD dengan iklim dan kepadatan penduduk dianalisis menggunakan uji korelasi Pearson dengan alternatif Spearman. Kelas kerawanan DBD diklasifikasikan dengan metode skoring dan pembobotan seperti berikut ini (Asniati et al., 2021): 


\section{Hasil dan Pembahasan}

Iklim Kota Medan pada tahun 2015 hingga 2020 meliputi suhu udara, kelembaban udara, dan curah hujan diperoleh dari stasiun Klimatologi Sampali, pada titik koordinat 3.6217 LU dan 98.7146 BT.

Suhu udara rata-rata di Kota Medan pada tahun 2015 - 2020 adalah $27,23{ }^{\circ} \mathrm{C}$. Data ini menginformasikan bahwa suhu udara di Kota Medan termasuk kategori suhu udara panas $\left(25^{\circ} \mathrm{C}-28^{\circ} \mathrm{C}\right)$. Puncak kasus DBD berada pada interval suhu $25,3^{\circ} \mathrm{C}-25,5^{\circ} \mathrm{C}$, yaitu 236 kasus pada bulan November dan 249 kasus pada bulan Desember. Menurut Tarmana (2017) bahwa keadaan tersebut optimal untuk perkembangbiakan nyamuk Aedes aegypti. Menurut Morin, Comrie, \& Ernst (2013) bahwa suhu tersebut ideal untuk semua siklus kelangsungan hidup nyamuk Aedes aegypti, yaitu suhu optimum nyamuk Aedes aegypti berada pada rentang $25-27$ ${ }^{0} \mathrm{C}$. Suhu ideal kelangsungan hidup nyamuk Aedes aegypti pada semua tahapan siklusnya adalah $20-30{ }^{\circ} \mathrm{C}$. Pada suhu $26{ }^{\circ} \mathrm{C}$ dan $28{ }^{\circ} \mathrm{C}$ masa inkubasi ekstrinsik virus dengue dalam tubuh nyamuk Aedes aegypti berkurang dari 9 hari menjadi 5. Suhu kurang dari $20{ }^{\circ} \mathrm{C}$ akan mempengaruhi siklus reproduksi nyamuk Aedes aegypti betina dimana fertilitas nyamuk betina berkurang pada suhu.

Hasil uji statistik menunjukkan bahwa terdapat hubungan antara suhu udara dengan kejadian DBD di Kota Medan tahun 2015 2020 dengan signifikan nilai $p=0,001<p_{0,05}$ dan $r=-0,374$, suhu udara memiliki korelasi sedang dan arah hubungan negatif, artinya jika suhu udara meningkat maka angka demam berdarah dengue akan turun atau sebaliknya. Penelitian ini sejalan dengan penelitian oleh (Arieskha et al., 2019) menunjukkan bahwa suhu udara menjadi faktor risiko dalam kejadian DBD di Kabupaten Tegal $(\mathrm{p}=0,023 ; \mathrm{r}=-0,821)$. Menurut Putri et al., (2020) bahwa terdapat hubungan bermakna antara suhu $(r=-0,342)$ dan kasus DBD di Kota Bandar Lampung dengan puncak kasus DBD terjadi antara 27,8 ${ }^{0} \mathrm{C}-28,8{ }^{0} \mathrm{C}$.

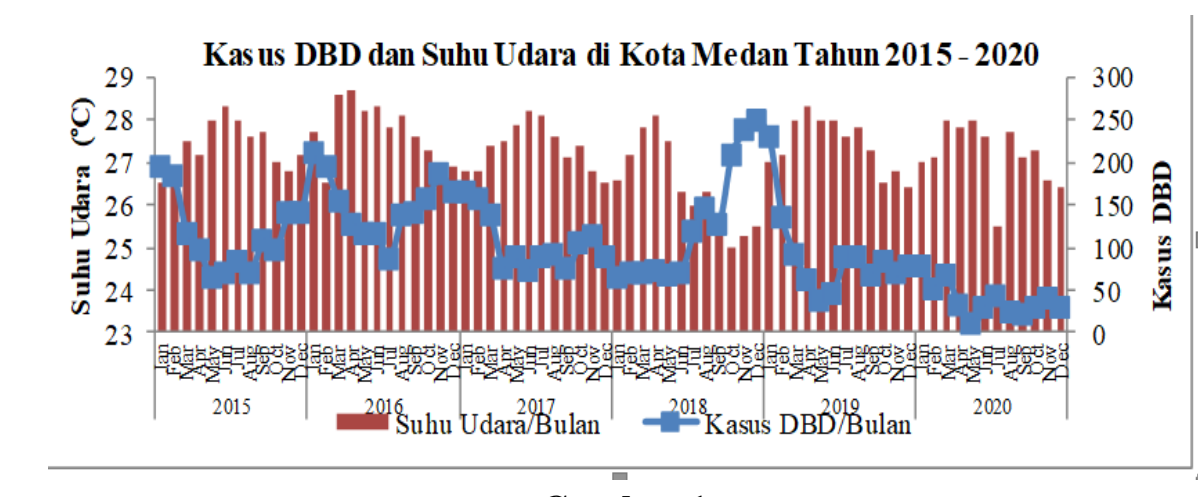

Gambar 1

Kasus DBD dan Suhu Udara Perbulan di Kota Medan Tahun 2015 - 2020

Kelembaban udara rata-rata di Kota Medan pada tahun 2015 - 2020 adalah $81,74 \%$. Data ini menginformasikan bahwa kelembaban udara di Kota Medan termasuk kategori kelembaban tinggi (70\% - 90\%). Puncak kasus DBD terjadi pada interval kelembaban udara 79\% - 80\%, yaitu 236 kasus pada bulan November dan 249 kasus pada bulan Desember. Penelitian ini didukung oleh (Juwita et al., 2021) menunjukkan bahwa DBD di Provinsi Jawa Barat pada tahun 2010 - 2019 tertinggi yaitu 5,052 kasus dan terendah 309 kasus dengan rata-rata kelembaban udara tertinggi sebesar $89,4 \%$ dan terendah sebesar 71,6\%.

Hasil uji statistik menunjukkan bahwa terdapat hubungan antara kelembaban udara dengan kejadian DBD di Kota Medan pada 
tahun $2015-2020$ dengan signifikan nilai $p=$ $0,001<p_{0,05}$ dan $\mathrm{r}=-0,370$, kelembaban udara memiliki korelasi sedang dan arah hubungan negatif, artinya ketika kelembaban udara naik maka angka demam berdarah dengue akan turun atau sebaliknya. Penelitian ini didukung oleh (Juwita et al., 2021) menunjukkan bahwa kelembaban udara rata-rata berhubungan terhadap jumlah kasus DBD ( $\mathrm{r}=0,64 ; \mathrm{p}<0,01)$. Penelitian Chandra (2019) menunjukkan bahwa kelembaban di Kota Jambi berpengaruh terhadap kejadian DBD $(\mathrm{r}=0,48$ atau $48 \%$ ) dengan kelembaban rata-rata $81 \%$.

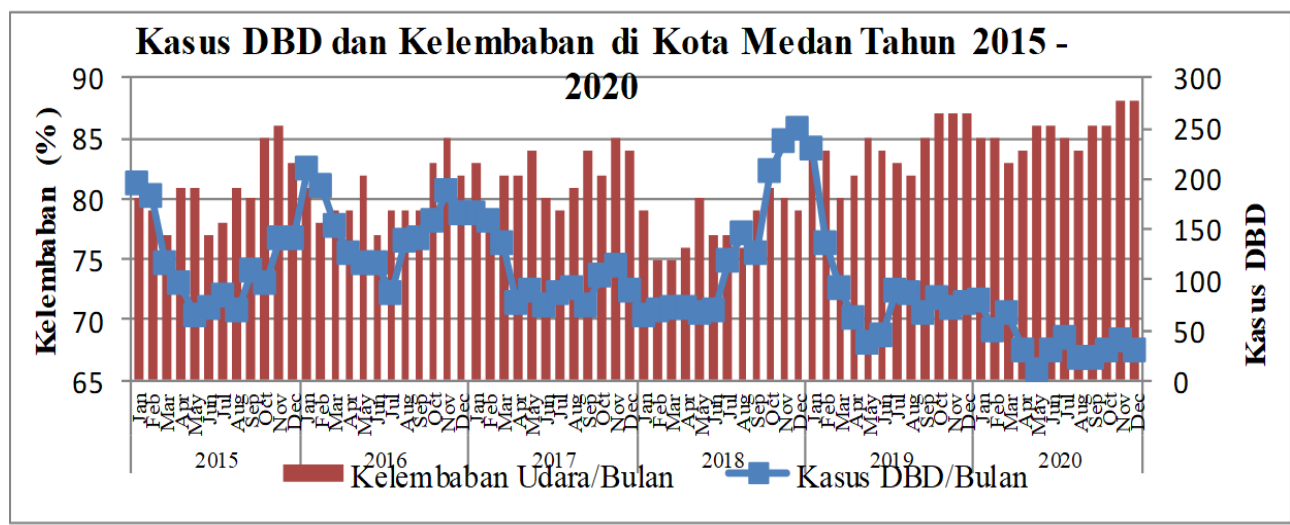

Gambar 2

Kasus DBD dan Kelembaban Udara Perbulan di Kota Medan Tahun 2015 - 2020

Curah hujan rata-rata di Kota Medan pada tahun 2015 - 2020 adalah $222,47 \mathrm{~mm}$. Data ini menginformasikan bahwa curah hujan di Kota Medan termasuk kategori curah hujan menegah (sedang) (100 $\mathrm{mm}-300$ $\mathrm{mm})$. Puncak kasus DBD berada pada interval curah hujan $311 \mathrm{~mm}-353 \mathrm{~mm}$, yaitu 236 kasus pada bulan November dan 249 kasus pada bulan Desember. Tarmana (Tarmana, 2017) menemukan bahwa curah hujan proyeksi tahun 2014 - 2038 sesuai dengan demam berdarah adalah $100-300 \mathrm{~mm}$.

Hasil uji statistik menunjukkan bahwa tidak terdapat hubungan antara suhu udara dengan kejadian DBD di Kota Medan pada tahun $2015-2020$ dengan signifikan nilai $p=$ $0,516>p_{0,05}$ dan $r=0,078$. Curah hujan secara teori dapat mempengaruhi kejadian DBD karena curah hujan berhubungan dengan siklus hidup nyamuk. Namun, curah hujan tinggi di Kota Medan tidak sepenuhnya berpengaruh terhadap peningkatan kasus DBD. Penelitian ini tidak sejalan dengan penelitian oleh (Zubaidah et al., 2016) menunjukkan bahwa curah hujan berkisar 275,4 mm hingga 391,1 mm meningkatkan KLB DBD di Kota Banjarbaru pada tahun $2004-2013$.

Hubungan yang tidak signifikan antara curah hujan dengan kejadian DBD di Kota Medan dimungkinkan terjadi karena perilaku masyarakat yaitu telah melakukan antisipasi dengan pemberantasan sarang nyamuk (PSN) sebelum musim penghujan datang. Bila dikaitkan dengan tempat perindukan nyamuk, tingginya curah hujan menyebabkan tempat perindukan nyamuk rusak karena airnya akan terus tumpah dari kontainer dan mengalir keluar, sehingga telur dan jentik nyamuk akan terbawa keluar mengakibatkan jumlah vektor menurun. 


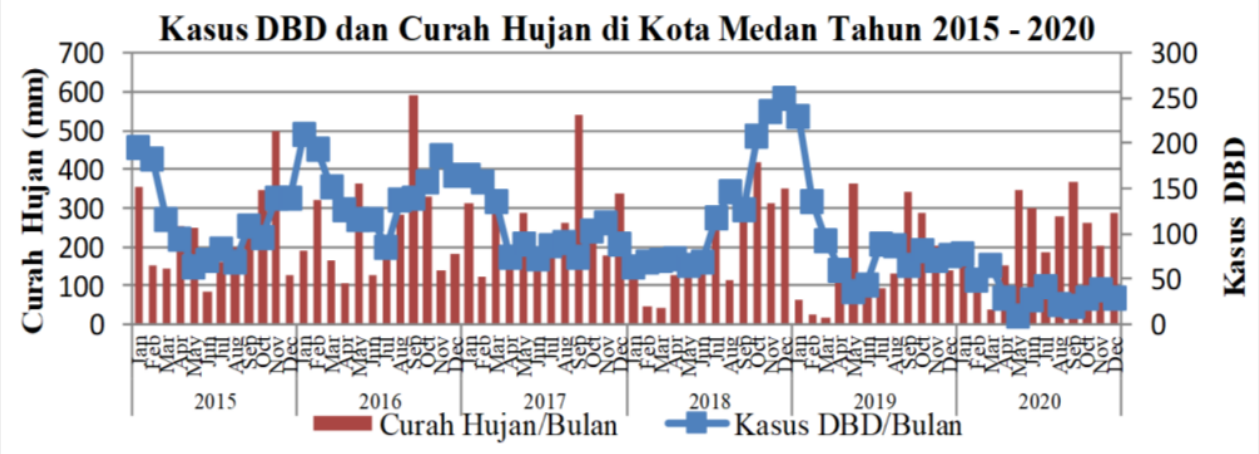

Gambar 3

Kasus DBD dan Curah Hujan Perbulan di Kota Medan Tahun 2015 - 2020

Kepadatan penduduk di Kota Medan pada tahun 2015 - 2020 adalah 8464 $\mathrm{Jiwa} / \mathrm{Km}^{2}$. Data ini menginformasikan bahwa kepadatan penduduk di Kota Medan termasuk kategori kepadatan penduduk sedang (500 $\left.10.000 \mathrm{jiwa} / \mathrm{km}^{2}\right)$. Jumlah kasus DBD tertinggi yaitu 696 kasus berada pada rata-rata kepadatan penduduk $9435,72 \mathrm{jiwa} / \mathrm{km}^{2}$ yaitu di Kecamatan Medan Johor, berjumlah 621 sedangkan jumlah kasus DBD terendah yaitu 147 kasus berada pada rata-rata kepadatan penduduk 14196,6 jiwa/ $/ \mathrm{km}^{2}$ yaitu di Kecamatan Medan Maimun.

Hasil uji statistik menunjukkan bahwa tidak terdapat hubungan antara kepadatan penduduk dengan kejadian DBD di Kota Medan pada tahun 2015 - 2020 dengan signifikan nilai $p=0,067>p_{0,05}$ dan $\mathrm{r}=-0,180$. Hasil penelitian ini tidak sejalan dengan penelitian oleh (Chandra, 2019) bahwa kepadatan penduduk di Kota Jambi memiliki hubungan rendah dengan kejadian DBD $(\mathrm{r}=0,153$ atau $15,3 \%)$ dan berpola positif artinya kepadatan penduduk semakin bertambah kemungkinannya kejadian DBD bertambah. Penelitian oleh Kasman \& Ishak (2018) menunjukkan bahwa secara spesifik Kecamatan Banjarmasin Utara memiliki korelasi kepadatan penduduk dengan kejadian $\operatorname{DBD}(\mathrm{p}=0,042 ; \mathrm{r}=0,892)$.

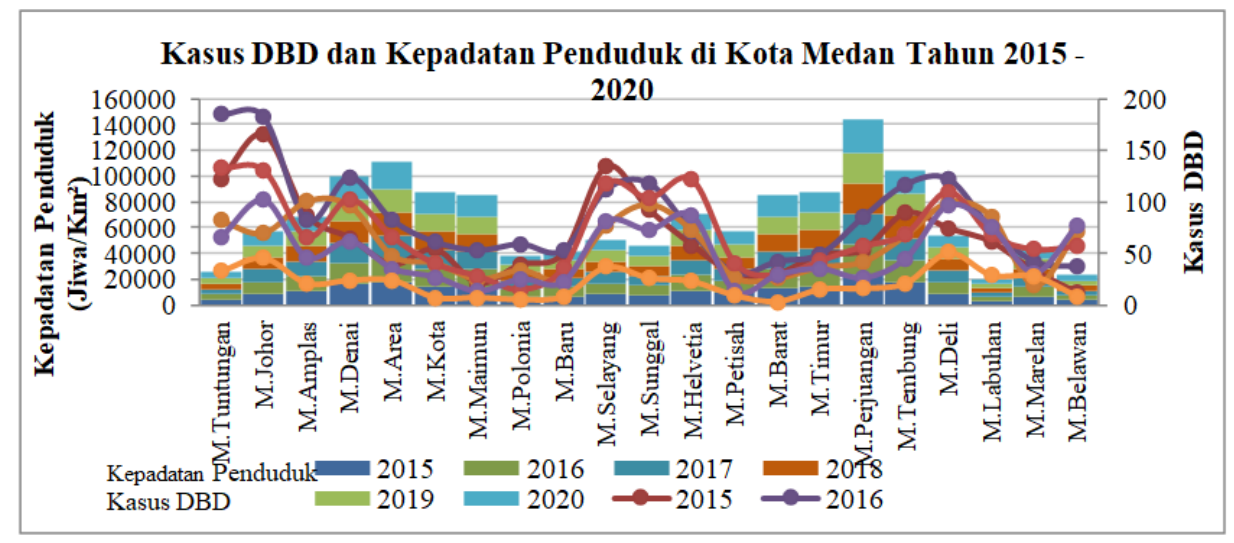

Gambar 4

Kasus DBD dan Kepadatan Penduduk Tahun 2015 - 2020 
Luas wilayah zona kerawanan tinggi DBD di Kota Medan padatahun 2015 - 2020 yaitu seluas 1541786 ha atau $73 \%$, sedangkan zona kerawanan sedang seluas 583258 ha atau $27 \%$. Kecamatan yang sesuai antara klasifikasi data kasus dengan hasil klasifikasi peta adalah Kecamatan Medan Tuntungan, Medan Johor, Medan Denai, Medan Selayang, Medan Sunggal, Medan Helvetia, dan Medan Deli merupakan daerah kerawanan tinggi DBD. Kecamatan Medan Amplas, Medan Area, Medan Kota, Medan Maimun, Medan Polonia, Medan Baru,
Medan Petisah, Medan Barat, Medan Barat, Medan Timur, Medan Perjuangan, Medan Tembung, Medan Labuhan, Medan Marelan, Medan Belawan merupakan zona kerawanan sedang, namun bertolak belakang dengan hasil perhitungan dari tingkat kerawanan DBD. Hal ini kemungkinan penderita terserang penyakit DBD bukan dari kecamatan tersebut melainkan ada kemungkinan dari kecamatan lain. Parameter yang digunakan terhadap jumlah kasus DBD di Kota Medan akurasi pemodelan spasial adalah $33 \%$.

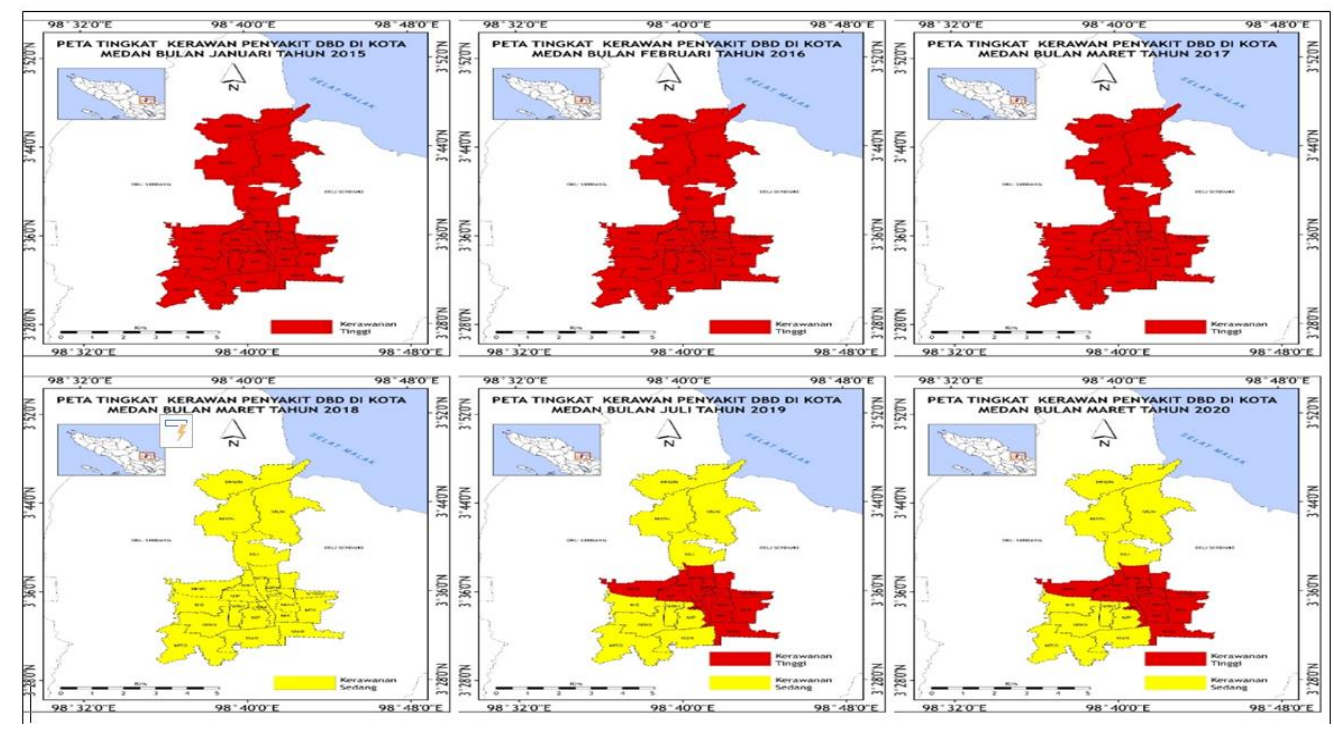

Gambar 5

Peta Tingkat Kerawanan Penyakit Demam Berdarah Dengue di Kota Medan Tahun 2015 $-2020$

\section{Kesimpulan}

Kejadian DBD di Kota Medan tahun 2015 - 2020 memiliki hubungan dengan suhu udara $(\mathrm{r}=-0,374$ dan $\mathrm{p}=0,001<\mathrm{p} 0,05)$, kelembaban udara $(\mathrm{r}=-0,370$ dan $\mathrm{p}=0,001<$ $\mathrm{p} 0,05)$, dan tidak memiliki hubungan dengan curah hujan $(\mathrm{r}=0,078$ dan $\mathrm{p}=0,516>\mathrm{p} 0,05)$, dan kepadatan penduduk $(\mathrm{p}=0,067>\mathrm{p} 0,05$ dan $r=-0,180$ ). Puncak kasus DBD berada pada bulan November yaitu 236 kasus dan bulan Desember yaitu 246 kasus berada pada interval suhu $25,3^{\circ} \mathrm{C}-25,5^{\circ} \mathrm{C}$, kelembaban $79 \%-80 \%$, curah hujan $311 \mathrm{~mm}-353 \mathrm{~mm}$, dan rata-rata kepadatan penduduk 9435,72 jiwa/km2 yaitu 696 kasus di Kecamatan Medan Johor. Kota Medan termasuk dalam zona rawan penyakit demam berdarah dengue. Kecamatan Medan Tuntungan, Medan Johor, Medan Denai, Medan Selayang, Medan Sunggal, Medan Helvetia, Medan Deli merupakan daerah kerawanan tinggi DBD.

Dinas Kesehatan Kota Medan, BMKG Sampali, dan Dinas Kependudukan Kota Medan dapat bekerjasama membuat sistem peringatan dini (early wanring system) 
peningkatan kasus DBD berdasarkan data suhu, kelembaban udara, curah hujan, dan wilayah dengan kepadatan penduduk tinggi. Hasil peringatan dini dapat ditindaklanjuti dengan melakukan upaya PSN dengan 3M plus serta membentuk Gerakan 1 Rumah 1 Jumantik. Data kasus DBD dan iklim yang disajikan masih terbatas dalam jangka waktu 6 tahun. Apabila dikemudian hari ingin dilakukan penelitian tentang perubahan iklim dan kepadatan penduduk disarankan menggunakan rentang waktu yang lebih panjang misalnya 10 tahun. Perlu dilakukan penelitian analisis spasial penyakit demam berdarah dengue dengan unit analisisnya wilayah kelurahan sehingga memberikan hasil analisis yang lebih spesifik

\section{BIBLIOGRAFI}

Arieskha, F. T. A., Rahardjo, M., \& Joko, T. (2019). The Association Between Weather Variability And Dengue Hemorrhagic Fever In Tegal Regency. Jurnal Kesehatan Lingkungan, 11(4), 339. Google Scholar

Asniati, A., Indirawati, S., \& Slamet, B. (2021). Analisis Sebaran Spasial Kerawanan Penyakit Demam Berdarah Dengue Tahun 2010 - 2019 Di Kota Banda Aceh. Jurnal Serambi Engineering, 6(1). Google Scholar

Badan Pusat Statistik Kota Medan. (2020). Badan Pusat Statistik Kota Medan Tahun 2020 (Badan Pusat Statistik (Ed.); P. 563). Badan Pusat Statistik Kota Medan. Google Scholar

Chandra, E. (2019). Pengaruh Faktor Iklim, Kepadatan Penduduk Dan Angka Bebas Jentik (ABJ) Terhadap Kejadian Demam Berdarah Dengue (DBD) Di Kota Jambi. Jurnal Pembangunan Berkelanjutan, 1(1), 1-15. Google Scholar
Dinas Kesehatan Provinsi Sumatera Utara. (2019). Profil Kesehatan Provinsi Sumatera Utara. In Jurnal Ilmiah Smart (Pp. 1-379). Dinas Kesehatan Provinsi Sumatera Utara. Google Scholar

Juwita, C. P., Anggiat, L., \& Budhyanti, W. (2021). Hubungan Kelembaban Udara Terhadap Kasus Demam Berdarah Dengue. Prosiding Seminar Nasional Kesehatan Poltekkes Kemenkes Surabaya 2020, 2(1), 1-5. Google Scholar

Kasman, K., \& Ishak, N. I. (2018). Analisis Penyebaran Penyakit Demam Berdarah Dengue Di Kota Banjarmasi Tahun 2012-2016. MPPKI (Media Publikasi Promosi Kesehatan Indonesia): The Indonesian Journal Of Health Promotion, 1(2), 32-39. Google Scholar

Kemenkes RI. (2017). Demam Berdarah Dengue Indonesia. In Pedoman Pencegahan Dan Pengendalian Demam Berdarah Di Indonesia (Vol. 5, Issue 7, P. 9). Kementerian Kesehatan RI. Google Scholar

Kemenkes RI. (2020). Profil Kesehatan Indonesia Tahun 2019. In M. Boga Hardhana, S.Si, MM Farida Sibuea, SKM, Msc.PH Winne Widiantini, SKM (Ed.), Short Textbook Of Preventive And Social Medicine (Pp. 1-497). Kementerian Kesehatan Republik Indonesia. Google Scholar

Morin, C. W., Comrie, A. C., \& Ernst, K. (2013). Climate And Dengue Transmission: Evidence And Implications. Environmental Health Perspectives, 121(11-12), 1264-1272. Google Scholar

Putri, D. F., Triwahyuni, T., Husna, I., Parasitologi, D., Kedokteran, F., Malahayati, U., Kedokteran, M., Kedokteran, F., \& Malahayati, U. (2020). Hubungan Faktor Suhu Dan Kelembaban Dengan Kasus Demam Berdarah Dengue ( DBD ) Di Kota Bandar Lampung The Relationship 
Between Temperature And Humidity Factors With Cases Of Dengue Hemorrhagic Fever ( DHF ) In Bandar Lampung City. Jurnal Analis Kesehatan, 9(1), 17-23. Google Scholar

Rahmanti, A. R., \& Prasetyo, A. K. N. (2012). Sistem Informasi Geografis: Trend Pemanfaatan Teknologi Informasi Untuk Bidang Terkait Kesehatan. Seminar Nasional Informatika Medis III (Snimed III), September, 6-12. Google Scholar

Soedarto. (2012). Demam Berdarah Dengue: Dengue Haemorrhagic Fever (Ed. 1). CV. Sagung Seto. Google Scholar

Sunaryo. (2015). Analisis Spasial Untuk Penyakit Berbasis Lingkungan. Seminar Nasional Upaya Pengendalian Penyakit Berbasis Wilayah. Google Scholar

Suwandono, A., Yuneu, M. I., Astuti, E. P., Wahono, T., Prasetyowati, H., Fuadzy, H., Widawati, M., Hendri, J., Ruliansyah, A., Fuadiyah, M. E. A.,
Pradani, F. Y., \& Nurindra, R. W. (2019). Menilik Perjalanan Dengue Di Jawa Barat (A. Suwandono (Ed.)). LIPI Press, Anggota Ikapi. Google Scholar

Tarmana, D. (2017). Potensi Peluang Demam Berdarah Dengue (DBD) Berdasarkan Proyeksi Perubahan Iklim (Study Kasus: DKI Jakarta). The Indonesian Journal Of Infectious Diseases, 1(2), 14. Google Scholar

Yana, Y., \& Rahayu, S. R. (2017). Analisis Spasial Faktor Lingkungan Dan Distribusi Kasus Demam Berdarah Dengue. HIGEIA (Journal Of Public Health Research And Development), 1(3). Google Scholar

Zubaidah, T., Ratodi, M., \& Marlinae, L. (2016). Pemanfaatan Informasi Iklim Sebagai Sinyal Peringatan Dini Kasus DBD Di Banjarbaru, Kalimantan Selatan. Vektora: Jurnal Vektor Dan Reservoir Penyakit, 8(2). Google Scholar

\section{Copyright holder:}

Sulastri Purba, Nurmaini Khalik, Sri Malem Indirawati (2022)

First publication right:

Jurnal Health Sains

This article is licensed under:

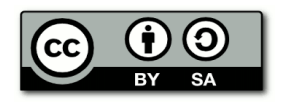

